\title{
Evaluasi Pasca Diklat Teknis Substantif PTK Pola Baru di Balai Diklat Keagamaan Denpasar \\ (Studi Kasus di Kantor Kementerian Agama Kota Mataram Tahun 2017)
}

Sifa

Balai Diklat Keagamaan Denpasar

\section{Keywords: \\ Post evaluation; \\ The impact of education and training; \\ Training for Substantive Technical Action Research for New Patterns}

\section{Kata kunci:}

Evaluasi;

Pasca diklat;

DTSPTK Pola baru

\section{ABSTRACT}

Abstract: The purpose of this study is to describe the impact of education and training (training) for Substantive Technical Action Research for New Patterns (DTSPTK New Patterns) on the competence of knowledge, skills, performance and career alumni of education and training at the Denpasar Religious Training Center, particularly in the Office of the Ministry of Religion in Mataram City. The New Pattern PTK Training is an innovation based on the Decree of the Head of Denpasar Religious Education Center number: B-1988 / Bdl.11 / 2 / KP.02.1 / 09/2016 dated September 26, 2016. The focus of this evaluation is the impact or benefits of education and training known as post training evaluation. The design of this research is in the form of a descriptive qualitative research by applying a combination of research methods (Mix methods research). This method researchers apply with the aim of obtaining comprehensive data. Data that is not possible to be captured through questionnaires, researchers obtained through in-depth interviews. The conclusion of the research shows that there is an impact of education and training on the application of knowledge competencies related to CAR in the assignment of alumni of the New Pattern CAR Training in Kota Mataram with effective results on the aspects of applying knowledge competencies related to CAR in the assignment (88.00\%), effective on aspects of applying competency skills related to CAR. 86.10\%), effective in improving performance (88.00\%), and effective in career advancement (87.10\%), and effective in the leadership support aspect (86.80\%), and effective in the aspect of change plan (85.90\%). The effectiveness of performance improvement is evidenced by the increased learning achievement of students (students) from DTSPTK New Pattern alumni. In the aspect of career advancement, there are at least 19 (nineteen) out of 30 training alumni or $63 \%$ who have utilized the results of classroom action research results for promotion. In the aspect of the change plan, there are at least nine new PTK titles that are ready to be carried out by the research of the New Pattern DTSPTK alumni in Mataram. Based on these conclusions, the recommendations given are that it is necessary to re-implement the New Pattern DTSPTK elsewhere in the BDK Denpasar working area.

Abstrak: Tujuan penelitian ini adalah untuk mendeskripsikan dampak pendidikan dan pelatihan (diklat) Teknis Substantif Penelitian Tindakan Kelas Pola Baru (DTSPTK Pola Baru) terhadap kompetensi pengetahuan, keterampilan, kinerja dan karir alumni diklat di Balai Diklat Keagamaan Denpasar, khususnya di Kantor Kementerian Agama Kota Mataram. Fokus evaluasi ini adalah dampak atau manfaat diklat yang dikenal dengan istilah evaluasi pasca diklat. Desain penelitian ini berupa penelitian deskriptif kuantitatif dan kualitatif (Mix methods research). Simpulan penelitian 
menunjukkan adanya dampak diklat terhadap penerapan kompetensi pengetahuan terkait PTK dengan hasil efektif (88.00\%), dampak diklat pada aspek penerapan kompetensi keterampilan terkait PTK menunjukkan hasil efektif (86.10\%), efektif juga dalam peningkatan kinerja $(88.00 \% \%)$, efektif dalam peningkatan karir $(87.10 \%)$, dan efektif pada aspek dukungan pimpinan (86.80\%), serta efektif pada aspek rencana perubahan (85.90\%). Terdapat peningkatan prestasi akademik baik oleh peserta didik dari para alumni maupun alumni itusendiri. Ada 62 prestasi akademik diraih peserta didik di bawah bimbingan para alumni DTSPTK Pola Baru mulai dari tingkat kota Mataram, provinsi NTB, dan nasional. Selain itu, satu prestasi akademik diraih pula oleh alumni. Terdapat 18 (delapan belas) alumni yang sudah memanfaatkan laporan Penelitian Tindakan Kelas hasil diklatnya untuk naik pangkat ke jenjang karir di atasnya. Pada aspek rencana perubahan, ada 9 (sembilan) judul Penelitian Tindakan Kelas yang baru dan siap untuk ditindaklanjuti menjadi sebuah hasil laporan penelitan Tndakan kelas. Karena menunjukkan efektivitas yang memadai, maka DTSPK Pola Baru dapat dijadikan salah satu alernatif dari diversifikasi diklat di BDK Denpasar khususnya, dan di BDK lain di Indonesia.

Correspondance address:

E-mail: sifakaelani69@gmail.com (Sifa)

\section{Pendahuluan}

Pendidikan dan pelatihan yang selanjutnya disingkat dengan diklat, merupakan upaya untuk meningkatkan kualitas sumber daya manusia (SDM). Hal ini sejalan dengan pendapat Gomes (2003) yang menyatakan bahwa pelatihan adalah setiap usaha untuk memperbaiki kinerja pegawai pada suatu pekerjaan tertentu yang sedang menjadi tanggung jawabnya atau suatu pekerjaan tertentu yang kaitannya dengan pekerjaan. Sumber daya manusia profesional sangat diperlukan dalam menjalankan organisasi pemerintahan termasuk di dalamnya lembaga pendidikan. Sumber daya manusia aparatur pemerintah yang profesional merupakan syarat penting dalam menghadapi tuntutan masyarakat yang saat ini kian berharap banyak pada aparatur pemerintah. Selain itu, aparatur pemerintah yang profesional juga diyakini dapat menjadi salah satu alternatif solusi dalam menghadapi tantangan global saat ini yang sudah masuk ke semua urusan termasuk bidang pendidikan.

Diklat sebagai proses yang terencana dan sistematis juga berdampak jangka panjang dalam membekali kompetensi aparatur pemerintah selama menjalankan tugas dan fungsinya. Diharapkan aparatur yang profesional akan mampu berkinerja tinggi sehingga stakeholder organisasi pemerintah tempat aparatur bekerja pun akan merasakan dampaknya. Apabila aparatur pemerintah sudah berkinerja tinggi maka visi dan misi organisasi tempat aparatur dimaksud bekerja pun bisa tercapai.

Efektivitas penyelenggaraan diklat akan diketahui jika dilaksanakan evaluasi. Karena itu, evaluasi dalam kediklatan mutlak diperlukan. Dengan demikian, program diklat tidak otomatis selesai seiring dengan berakhirnya kegiatan belajar mengajar di kelas. Ada beberapa pertanyaan bisa saja baru teridentifikasi setelah diklat usai dilaksanakan, bahkan setelah peserta kembali ke tempat tugas mereka masing-masing. Kegiatan untuk mengetahui apakah tujuan diklat tercapai, atau apakah ada pengaruh diklat terhadap perubahan perilaku, pengetahuan, maupun keterampilan. Alumni diklat, sering dikenal dengan istilah evaluasi diklat. Pertanyaan-pertanyaan tersebut bisa dijawab dengan akurat apabila dilakukan evaluasi pasca diklat.

Hal ini untuk mengetahui ketercapaian tujuan diklat sebagaimana tercantum dalam Pearturan Menteri Agama (PMA) nomor 75 Tahun 2015 tentang Penyelenggaraan Pendidikan dan Pelatihan adalah meningkatkan pengetahuan, keahlian, keterampilan, dan sikap pegawai untuk 
dapat melaksanakan tugas jabatan secara profesional yang dilandasi kepribadian dan kode etik pegawai sesuai kebutuhan Kementerian Agama (PMA No. 75 Tahun 2015 Pasal 2).

Berbagai kalangan mengatakan bahwa tidak ada perbedaan hasil yang mencolok antara setelah pelatihan dengan sebelum pelatihan. Benarkah demikian? Benarkah pegawai yang telah dilatih tidak ada perbedaan nyata dengan pegawai sebelum pelatihan? Pertanyaan ini perlu dijawab dengan bukti. Untuk membuktikan hal tersebut, maka perlu dilakukan Evaluasi Program Pasca Diklat.

Diklat Teknis Substantif Penelitian Tindakan Kelas Pola Baru selanjutnya disingkat DTSPTK Pola Baru merupakan salah satu bentuk inovasi di Balai Diklat Keagamaan Denpasar berdasarkan SK Kepala BDK Denpasar nomor B-1988/Bdl.11/2/KP.02.1/09/2016 tanggal 26 September 2016. Mengingat DTS PTK Pola Baru merupakan salah satu diklat inovasi sekaligus sebagai diklat unggulan di Balai Diklat Keagamaan Denpasar dan belum diketahui dampak diklat terhadap alumni diklat, maka evaluasi pasca diklat menjadi perlu dilakukan.

Wilayah kerja Balai Diklat Keagamaan Denpasar meliputi tiga provinsi, yakni Bali, NTB, dan NTT. Namun demikian, untuk Diklat Teknis Substantif PTK Pola Baru baru dilaksanakan di Bali dan NTB, dikarenakan keterbatasan anggaran di NTT.

Diklat Teknis Substantif PTK Pola Baru pertama kali dilaksanakan di Provinsi Bali pada akhir tahun 2016 yakni di Kantor Kementerian Agama Kabupaten Jembrana. Kedua kalinya dilaksanakan di Provinsi NTB yakni di Kota Mataram pada tahun 2017. Pada tahun 2018 Penelitian evaluasi pasca diklat dengan fokus pada satu wilayah yakni di Kantor Kementerian Agama Kota Mataram.

Peneliti membatasi ruang lingkup permasalahan meliputi pendeskripsian terhadap dampak DTSPTK Pola Baru terhadap: (1) penerapan kompetensi pengetahuan terkait PTK di tempat tugas; (2) penerapan kompetensi keterampilan terkait PTK di tempat tugas; (3) peningkatan kinerja; (4) peningkatan karir; dan (5) dukungan pimpinan terhadap pelaksanaan Penelitian Tindakan Kelas oleh alumni; serta (6) rencana perubahan yang akan dilakukan.

\section{Metode}

Metode penelitian yang diterapkan dalam peneltian ini adalah mixed methods. Hal ini didasari oleh tujuan penelitian, yakni untuk mendeskripsikan secara komprehensif dampak diklat teknis substantif penelitian tindakan kelas pola baru terhadap alumni diklat.

Data yang diperoleh pada penelitian ini berupa data kuantitatif dan data kualitatif. Data kuantitatif bersumber dari hasil kuesioner tentang dampak diklat terhadap kompetensi alumni dan data kualitatif bersumber dari hasil wawancara peneliti dengan partisipan terkait dampak diklat terhadap peserta didik, kinerja alumni, dan karir alumni. Sugiyono (2011) menyatakan bahwa metode penelitian kombinasi (mixed methods) adalah suatu metode yang mengombinasikan atau menggabungkan antara metode kuantitatif dengan metode kualitatif untuk digunakan secara bersama-sama dalam suatu kegiatan penelitian sehingga diperoleh data yang lebih komprehensif, valid, reliabel, dan objektif.

Adapun langkah-langkah metode yang digunakan dalam penelitian ini meliputi: (1) rancangan penelitian, (2) subjek penelitian, (3) teknik pengumpulan data, (4) instrument penelitian, dan (5) analisis data.

Subjek penelitian ini adalah 30 alumni Diklat Teknis Substantif PTK Pola Baru, yakni guru Madrasah di Kota Mataram. Dari 30 responden tersebut ada 19 responden yang diwawancarai untuk mengkonfirmasi jawaban yang sudah ditulis dalam kuesioner.

Penelitian ini menggunakan metode angket atau kuesioner dan wawancara. Metode angket atau kuesioner. Metode ini digunakan untuk memperoleh data tentang: (1) dampak DTSPTK Pola Baru terhadap penerapan kompetensi pengetahuan; (2) dampak DTSPTK Pola Baru terhadap penerapan kompetensi keterampilan dalam ber-PTK; (3) dampak terhadap peningkatan kinerja alumni; (4) dampak terhadap peningkatan karir; (5) data tentang rencana perubahan; serta (6) data tentang dukungan pimpinan terhadap pelaksanaan penelitian tindakan kelas yang dilakukan alumni. 
Peneliti menggunakan angket atau kuesioner yakni berupa pertanyaan tertulis untuk mendapatkan informsi yang diperlukan. Respon pertanyaan ini diberi skor yang mengacu kepada skala Likert. Skala Likert digunakan untuk mengukur sikap, pendapat, dan persepsi seseorang tentang suatu fenomena sosial Untuk kepentingan kuantitatif maka jawaban dapat diberi skor. Kuesioner digunakan untuk memperoleh informasi terkait perubahan perilaku alumni sekembalinya ke tempat tugas. Kuesioner yang kedua ini diberikan kepada alumni dan teman sejawat, serta atasan langsung alumni diklat. Hal ini dimaksudkan untuk memperoleh akurasi data. Sebelum angket/ kuesioner digunakan, peneliti melakukan uji validitas dan reliabilitas. Uji validitas yang ditetapkan dalam penelitian ini dengan menerapkan rumus product moment. Dari uji validitas yang dilakukan pada tanggal 1 Maret 2018 diperoleh hasil kuesioner yang disebarkan valid dan reliabel dengan menggunakan rumus person product moment diperoleh angka Alpha Cronbach $\left(r_{11}\right)$ sebesar $0,9846$.

Prosedur Analisis Data Explanatory Sequential Mixed Methods tampak pada gambar 02

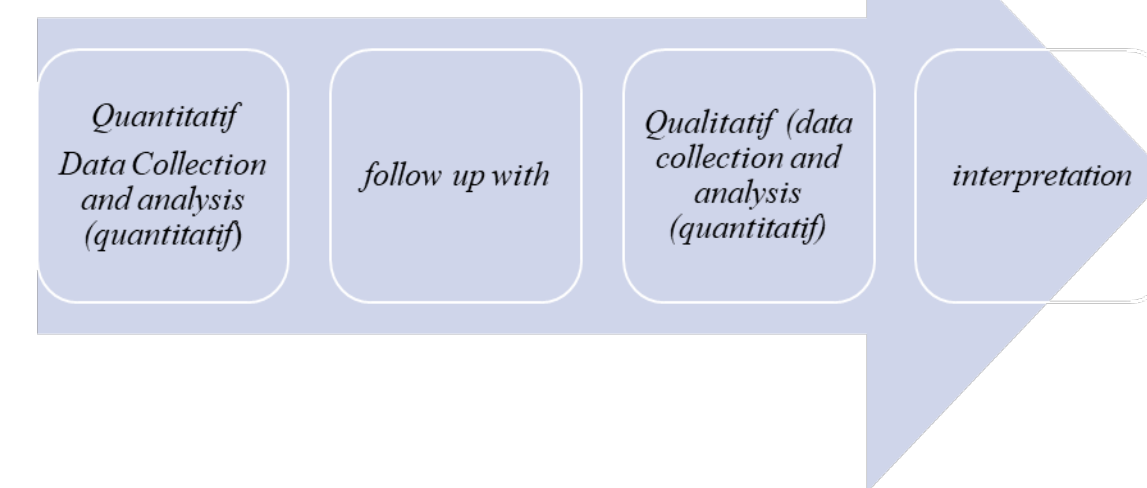

\section{Gambar 02 Basic Methods Design "Explanatory Sequential Mixed Methods (Cresswell: 2014:269)}

\section{Analisis Data Kuantitatif}

Data kuantitatif berupa angket / kuesioner dampak Diklat Teknis Substantif PTK Pola baru terhadap kompetensi pengetahuan dan keterampilan dianalisis melalui distribusi frekuensi dengan memberikan presentase, dalam hal ini peneliti menggunakan rumus sebagai berikut.

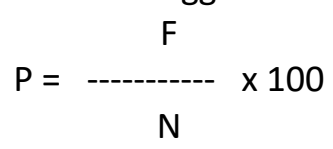

Keterangan:

$\mathrm{P}=$ Angka persentase, $\mathrm{F}=$ Frekuensi (jumlah jawaban responden), $\mathrm{N}=$ Number of Cases (jumlah frekuensi atau banyaknya individu)

Analisis selanjutnya untuk mencari rata-rata (Mean) persentase skor efektivitas pelaksanaan Diklat dengan menggunakan rumus sebagai berikut.

$$
M \%=\left\{\frac{M}{\text { sMI }}\right\} \times 100 \% \text { ( Agung, 2014;144) }
$$

Untuk mengetahui tingkatan efektivitas variabel yang diteliti, rata-rata persen (M\%) yang telah didapatkan dibandingkan ke skala PAP skala lima dengan kriteria sbb: 
Tabel 3.2 Pedoman Konversi PAP Skala V

\begin{tabular}{|c|c|c|c|}
\hline [1] & Persentase & [2] & Kriteria \\
\hline [3] & $90-100$ & [4] & Sangat efektif \\
\hline [5] & $80-89$ & [6] & Efektif \\
\hline [7] & $65-79$ & [8] & Cukup efektif \\
\hline & $55-64$ & [10] & Kurang efektif \\
\hline [11 & $0-54$ & [12] & Tidak efektif \\
\hline
\end{tabular}

Sumber: (Agung, 2014; 145)

Analisis data kuantitatif dalam penelitian ini merupakan jawaban dari rumusan masalah.,iperkuat dengan data kualitatif sebagai hasil wawancara dengan partisipan.

\section{Analisis Data Kualitatif}

Menurut Mathew B Miles psikolog, dan Michael Huberman ahli pendidikan dari university of Genava, Switzerland, analisis kualitatif data yang muncul berwujud kata bukan angka. Data yang sudah terkumpul dari hasil wawancara, pengamatan, maupun dokumentasi diproses atau disusun dalam bentuk teks yang diperluas (Patilima, 2007: 96).

Menurut Patton, Bogdan, dan Taylor (dalam Arifin, 2003:78) analisis data adalah suatu proses mengorganisasikan data dan mengurutkan data ke dalam pola, kategori , dan satuan uraian dasar sehingga dapat ditemukan tema dan dapat dirumuskan hipotesis kerja sesuai dengan data. Matthew B Miles dan A Michael Huberman (1992) menyatakan bahwa dalam analisis data terdapat tiga alur kegiatan yang terjadi secara bersamaan.

\section{Hasil dan Pembahasan}

Hasil penelitian ini diklasifikasikan dalam dua kelompok data yakni data kuantitatif dan data kualitatif. Data kuantitatif yang dimaksud berupa informasi yang bersumber dari kuesioner, sedangkan data kualitatif dalam penelitian ini berupa hasil wawancara mendalam kepada informan alumni Diklat PTK Pola baru di Kantor Kementerian Agama kota Mataram. Data peneliti peroleh pada tahun 2018 disusun dan dianalisis berdasarkan metode penelitian yang digunakan dalam penelitian ini yakni mixed methods.

\section{Evaluasi Pasca Diklat Secara Umum}

Berikut ini disajikan data hasil evaluasi yang bersumber dari kuesioner yang diisi oleh alumni diklat Teknis PTK Pola Baru Tahun 2017 oleh para guru madrasah di Kantor Kementerian Agama Kota Mataram. Secara umum evaluasi pasca diklat Teknis Substantif PTK Pola Baru di Kantor Kementerian Agama Kota Mataram efektif (86,23\%). Hal ini didasarkan pada data kuantitatif berupa kuesioner yang berhasil kembali dikumpulkan dari 30 (tiga puluh) alumni seperti tampak pada Tabel 4.1

Tabel 4.1 Dampak Diklat PTK Pola Baru di Kankemenag Kota Mataram

\begin{tabular}{|c|c|c|c|}
\hline No & Uraian & Persentase & Kategori \\
\hline 1 & $\begin{array}{l}\text { Penerapan Kompetensi Pengetahuan terkait PTK di } \\
\text { tempat tugas }\end{array}$ & $88.00 \%$ & efektif \\
\hline 2 & $\begin{array}{l}\text { Penerapan Kompetensi keterampilan terkait PTK di } \\
\text { tempat tugas }\end{array}$ & $86.10 \%$ & efektif \\
\hline 3 & Peningkatan Kinerja & $88,00 \%$ & efektif \\
\hline 4 & Peningkatan karir & $87.10 \%$ & efektif \\
\hline
\end{tabular}




\begin{tabular}{llll}
\hline $\mathbf{5}$ & Dukungan dari Pimpinan & $86.80 \%$ & efektif \\
\hline $\mathbf{6}$ & Rencana Perubahan & $85.90 \%$ & efektif \\
\hline & Rerata (mean) & $86,23 \%$ & Efektif \\
\hline
\end{tabular}

\section{Evaluasi Pasca Diklat Perindikator}

Dari 30 responden yang mengisi kuesioner, ada 19 informan yang berhasil peneliti wawancari. Kedua puluh informan dimaksud terdiri atas 6 guru MAN 1 Mataram, 1 guru MAN 2 Mataram, 4 guru MTsN 2 Mataram, 2 guru MTsN 1 Mataram, 2 guru MTs N 3 Mataram, 2 guru MIN 1 Mataram dan 2 guru MIN 2 Mataram. Hasil analisis kuantitatif dilengkapi dengan analisis kualitatif dari hasil wawancara mendalam dapat diuraikan pada paparan berikut ini.

\section{Penerapan Kompetensi Pengetahuan terkait PTK di tempat tugas}

Berdasarkan hasil wawancara terhadap alumni diklat, pada umumnya mereka sudah memahami konsep dasar penelitian tindakan kelas, proposal, instrumen, dan laporan hasil Penelitian Tindakan Kelas dan mampu menerapkannya di tempat tugas. Hal ini tampak dari jawaban alumni yang mendeskripsikan konsep-konsep dasar penelitian tindakan kelas dengan menggunakan bahasa mereka sendiri. Beberapa jawaban alumni tampak pada hasil wawancara di bawah ini.

Informan 16: "Konsep dasar PTK adalah penelitian yang dilaksanakan oleh seorang pendidik di sebuah kelas yang diajarkannya yang mengalami permasalahn dan mencarikan solusi pemecahannya yang dilaksanakan pada jam pembelajaran di kelas tersebut melalui beberapa siklus dengan melaksanakan 4 tahap yaitu perencanaan, pelaksanaan, observasi, refleksi"

Informan yang lain menyatakan bahwa:

Informan 17: "Konsep dasar PTK adalah sebuah langkah yang ditempuh oleh guru untuk memperbaiki kualitas atau kemapuan siswa dalam menguasai suatu materi pelajaran tertentu dengan mengubah metode/strategi/pendekatan pembelajaran ataupun medianya melalui beberapa siklus untk memperoleh hasil yang diinginkan"

Dari jawaban dua informan tersebut dapat menunjukkan bukti pemahaman terhadap konsep dasar PTK. Informan berikutnya menyatakan dampak diklat PTK Pola Baru terhadap alumni seperti pada kutipan hasil wawancara,

informan 01 "Dampak PTK Pola Baru menambah wawasan dan pengalaman dampaknya luar biasa. memperbaiki pola pikir mindset tentang PTK itu sulit, ternyata hasil PTK yang baru sudah ada dan sudah diseminarkan"

Selain memahami konsep dasar PTK, alumni diklat juga sudah memahami tentang konsep proposal PTK. Hal ini tampak pada pernyataan tiga informan:

Informan 16: "Proposal PTK adalah rencana yang disusun oleh guru sebelum menyusun PTK setelah melihat hasil belajar yang kurang memuaskan dan ingin memperbaikinya. Proposal PTK meliputi latar belakang, tinjauan teori yang mendukung dan rencana langkah - langkah yang akan ditempuh dalam memperbaiki hasil belajar"

Informan 18 menyatakan bahwa proposal PTK adalah: " Rancangan kegiatan secara keseluruhan tentang penelitian tindakan kelas" (017); "Proposal PTK merupakan rencana awal sebelum pelaksanaan PTK" 
Dari informasi mengenai konsep proposal menunjukkan tingkat pemahaman yang bervariasi. Ada yang memahami secara detil, ada pula yang memahami secara substantif tentang konsep proposal PTK. Demikian juga pemahaman terhadap konsep instrumen PTK dan Laporan PTK, pada umumnya alumni sudah cukup memadai. Hal ini terbukti dari pernyataan berikut:

Informan 16: "Instrumen PTK merupakan instrument-instrumen yang kita rancang selama melaksanakan PTK baik instrument observasi, instrument test dan lain- lain."

"Laporan PTK adalah laporan yang disusun selama penelitian yang mencakup kegiatan perencanaan, pelaksanaan, pengamatan, dan refleksi termasuk evaluasi sampai hasil dari sebuah PTK"

Jika dikaitkan dengan data kuantitatif hasil kuesioner pada angka $88.00 \%$, maka dapat dikatakan Diklat PTK Pola baru ini efektif dalam penerapan kompetensi pengetahuan di tempat tugas.

\section{Penerapan Kompetensi Keterampilan Terkait PTK di Tempat Tugas}

Penerapan kompetensi keterampilan terkait PTK di tempat tugas dapat dibuktikan dengan kemampuan alumni dalam melaksanakan proses belajar mengajar, yakni kemampuan menerapkan berbagai model pembelajaran dalam rangka meningkatkan kualitas pembelajaran, berdasarkan permasalahan kelas yang dijumpainya. Bersumber kepada upaya meningkatkan kualitas pembelajaran di kelas melalui penerapan berbagai model pembelajaran, maka PTK dapat dilaporkan sesuai dengan konsep prosedurnya.

Dari hasil wawancara terbukti ada beberapa informan yang dengan penuh kesadaran mencoba menerapkan berbagai model pembelajaran inovatif yang lain, guna meningkatkan aktivitas maupun interaksi selama proses pembelajaran. Petikan wawancara berikut dapat dijadikan salah satu bukti.

Informan 01" Pengalaman saya mengikuti diklat PTK Pola baru sangat menyenangkan. Karena dalam pelatihan ini kita benar - benar dibimbing untuk menyusun PTK dari tahap awal sampai tahap akhir didampingi oleh widyaiswara. mulai dari penyusunan proposal, tindakan, sampai pelaporan. pelaksanaan tindakan dan penyusunan laporan sampai seminar. Biasanya saya mengikuti pelatihan yang sebelumnya, produk disusun secara mandiri. Dalam pelatihan Diklat PTK Pola baru ini kita didampingi hingga laporan PTKnya selesai. Dampak bagi guru sendiri dapat lebih menguasai bagaimana menyusun PTK yang baik. Dan lebih terarah dalam melaksanakan proses pembelajaran "

Pernyataan di atas sangat relevan dengan data kuesioner terhadap penerapan kompetensi keterampilan di tempat tugas yakni di angka $86,10 \%$ (efektif).

\section{Peningkatan Kinerja}

Dari hasil kuesioner pada aspek peningkatan kinerja yakni sebesar 88\%, yakni dapat dikatakan efektif. Pada aspek peningkatan kinerja, DTSPTK Pola Baru berdampak pula terhadap peningkatan kinerja. Meskipun demikian, ada pula informan yang menyatakan kekhawatirannya untuk mampu bertahan dalam menerapkan keterampilan berPTK selama proses pembelajaran karena adanya istilah "kejar target" terutama bagi guru yang mengajar di kelas akhir.

(informan ....)" sebagaimana konsep PTK : kalau kita mengacu pada tujuan PTK itu sendiri bagaimana mengobati kelas yang sakit. ketika kelas sakit dikasih obat yang mujarab maka kelas yang sakit jadi sembuh. masalah yang di kelas bisa terselesaikan Ketika diterapkan kepada Anak (siswa), anak lebih mampu /mudah menguasai materi. Masalah bagi guru : jangan sampai guru berinovasi ketika berPTK saja, setelah tidak ber-PTK kembali seperti semula. karena kejar materi sesuai target kendala 
adanya ujian bersama di kota Mataram. problematika ibu bapak guru: jangan sampai ketika ber-PTK saja memperbaiki pembelajaran"

Peningkatan kinerja dapat juga dibuktikan dari prestasi peserta didik alumni diklat PTK Pola Baru, seperti siswa dari ibu Heny Marlina dan ibu Jundani guru MIN 2 Mataram yang berhasil membimbing peserta didiknya lolos pada ajang Kompetisi Sains dan Matematika Tingkat Kota Mataram, bahkan tembus sampai provinsi Nusa Tenggara Barat. Secara terperinci prestasi peserta yang diraih oleh peserta didik alumni DTSPTK Pola baru yang sempat peneliti himpun dari jenjang MI, MTs, dan MA berjumlah 35 (tiga puluh) siswa lolos pada lomba- lomba di tingkat kota Mataram, dan 16 (enam belas) prestasi di tingkat provinsi NTB, dan 5 (lima) prestasi di tingkat nasional termasuk perolehan nilai Ujian Nasional (UN) tertinggi mata pelajaran Ekonomi Madrasah Aliyah yang diraih oleh peserta didik asal MAN 1 di bawah bimbingan alumni diklat atas nama H. Jupri, SE, ME. dan satu prestasi olimpiade Matematika tingkat internasional yakni peserta didik asal MTsN 1 Mataram atas nama M Rafsyah Sefyuana di bawah bimbingan alumni diklat atas nama Muhbahir, S.Pd. Selain prestasi yang diraih oleh peserta didik, terdapat prestasi yang diraih oleh alumni DTSPTK Pola baru atas nama Dra. $\mathrm{Hj}$. Baiq Nur sukyalaili guru MAN 1 Mataram, sebagai peraih juara 1 Lomba Guru Anugerah Konstitusi dan mendapat penghargaan langsung dari Mahkamah Konstitusi, Jakarta.

Demikian juga prestasi yang diraih oleh peserta didik alumni DTSPTK Pola Baru di MTs N 3 Mataram, MTsN 2 Mataram dan MTsN 1 Mataramyang berhasil mengantarkan peserta didiknya lolos di lomba- lomba prestasi akademik di tingkat kota Mataram, yakni meraih juara pada KSM IPS terpadu, lomba OSN, KSM maupun olimpiade mata pelajaran yang lain.

\section{Peningkatan Karir}

Dampak pelaksanaan PTK Pola Baru pada aspek peningkatan karir tampak cukup bervariasi. Informasi dari hasil kuesioner menunjukkan angka 87.10\% (efektif). Berdasarkan hasil wawancara, responden yang menyatakan bahwa hasil Laporan PTK Pola Baru sudah dimanfaatkan untuk kenaikan pangkat berjumlah 18 orang (60\%). Setelah didalami, ada beberapa penyebab para alumni belum memanfaatkan hasil Laporan seminar PTK- nya sebagai unsur kenaikan pangkat. Diantaranya adalah ada beberapa guru yang baru saja mengusulkan kenaikan pangkatnya pada tahun 2017, sehingga untuk mengusulkan kembali mesti menunggu sampai jumlah angka kredit dari unsur pembelajaran terpenuhi. Seperti pernyataan informan (04).

Informan 04 :"Posisi saya saat ini sudah Gol IV a. Sekarang sedang mencoba mengusulkan ke IVb"

\section{Dukungan dari Pimpinan}

Dari kuesioner menunjukkan angka $86.80 \%$, dalam kategori efektif. Dukungan dari pimpinan dalam pelaksanaan tugas guru di madrasah, khususnya pada proses pelaksanaan Diklat PTK Pola Baru rata- rata menyatakan bahwa pimpinan sangat mendukung kegiatan ini.

\section{Informan 16 "Respon Kepala Madrasah sangat mendukung dan memfasilitasi"}

Informan 17 "Pimpinan madrasah sangat mendukung bahkan memotivasi kepada semua rekan guru-guru untuk melaksanakan PTK"

\section{Rencana Perubahan}

Selain kinerja, output lain dalam penyelenggaraan diklat adalah munculnya proyek perubahan yang berbentuk inovasi. Sedangkan pada level outcome, alumni diharapkan mampu mendorong budaya inovatif di lembaga dengan mampu membangun inovasi-inovasi sesuai dengan kebutuhan dan kapasitas lembaga (Ervina Yunita, 2017:9).

Mengacu kepada konsep ini, maka rencana perubahan dapat dikatakan sebagai salah satu tolok ukur keberhasilan diklat. Berdasarkan hasil wawancara dengan alumni diperoleh informasi bahwa ada 9 alumni DTSPTK Pola baru yang menulis PTK yang baru, seperti tampak pada Tabel 4.2. 
Adapun alumni yang belum sempat menulis PTK lainnya disebabkan oleh banyak hal. Antara lain kesibukan sebagai wali kelas, kesibukan sebagai bendahara madrasah, dan hal-hal lain yang sifatnya individual.

Jika data ini kita kaitkan dengan data kuesioner pada aspek rencana perubahan yakni di angka $85.90 \%$ (efektif), maka kurang sinkron. Mestinya jumlah rencana judul baru alumni mencapai $85 \%$, yakni berjumlah sekurang - kurangnya 25 judul PTK baru. Namun kenyataan baru 9 judul baru atau $30 \%$ yang sempat peneliti inventarisir.

Tabel 4.2 Daftar Judul Penelitian Tindakan Kelas Alumni DTSPTK Pola Baru di Kankemenag Kota Mataram Tahun 2018

\begin{tabular}{|c|c|c|}
\hline 13] No & 4] Nama & 5]. \\
\hline [16] 1 & $\begin{array}{l}\text { [17] Heny } \\
\text { Marlina }\end{array}$ & $\begin{array}{l}\text { [18] Peningkatan Minat dan Hasil Belajar Siswa Kelas VIA MIN } 2 \\
\text { Mataram pada Pembelajaran Tematik melalui Strategi } \\
\text { Pembelajaran Inkuiri }\end{array}$ \\
\hline [19] 2 & $\begin{array}{l}\text { [20] } \mathrm{He} \\
\mathrm{M}\end{array}$ & $\begin{array}{l}\text { [21] Upaya Peningkatan Minat dan Hasil Belajar Siswa Kelas VI B pada } \\
\text { Pembelajaran Tematik melalui Metode Memory Power di MIN } 2 \\
\text { Mataram }\end{array}$ \\
\hline [22] 3 & $\begin{array}{l}\text { [23] Sarton } \\
\text { Ramli }\end{array}$ & $\begin{array}{l}\text { [24] Penerapan Pembelajaran Model Group Investigation untuk } \\
\text { Meningkatkan Motivasi dan Hasil Belajar Siswa Kelas XII MAN } 1 \\
\text { Mataram }\end{array}$ \\
\hline [25] 4 & $\begin{array}{l}\text { [26] Bq } \\
\text { Nursyukyalai } \\
\text { ly }\end{array}$ & $\begin{array}{l}\text { [27] Penerapan Model PBI terhadap Peningkatan Hasil Belajar PPKn } \\
\text { pada Kelas XII Mia } 2 \text { MAN } 1 \text { Mataram }\end{array}$ \\
\hline [28] 5 & [29] Bq & $\begin{array}{l}\text { [30] Penerapan Media gambar untuk Meningkatkan Hasil Belajar } \\
\text { Siswa Kelas I C MIN I Mataram }\end{array}$ \\
\hline [31] 6 & [32] Asiah & $\begin{array}{l}\text { [33] Penerapan Media Audio Visual untuk Meningkatkan Hasil Belajar } \\
\text { Siswa Kelas Ib MIN I Mataram }\end{array}$ \\
\hline [34] 7 & [35] Jur & $\begin{array}{l}\text { [36] Upaya Peningkatan Hasil Belajar Matematika Kelas V MIN } 2 \\
\text { Mataram melalui Penerapan Model TGT }\end{array}$ \\
\hline [37] 8 & [38] Hurr & $\begin{array}{l}\text { [39] Penerapan Model Problem Based Learning dalam Meningkatkan } \\
\text { Hasil Belajar Peserta Didik Kelas IX c MTs } 2 \text { Mataram }\end{array}$ \\
\hline [40] 9 & $\begin{array}{l}\text { [41] Zuhri } \\
\text { Agustiani, } \\
\text { S.Pd }\end{array}$ & $\begin{array}{l}\text { [42] Penerapan Model Problem Based Learning dalam Meningkatkan } \\
\text { Hasil Belajar Peserta didik Kelas IX b Materi Perubahan Sastra } \\
\text { Budaya di MTsN } 2 \text { Mataram Tahun 2018/2019 }\end{array}$ \\
\hline
\end{tabular}

\section{Pembahasan}

Dampak DTSPTK Pola Baru terhadap Penerapan Kompetensi Pengetahuan

Alumni DTSPTK Pola Baru secara umum sudah memahami konsep PTK,Proposal PTK, Instrumen PTK serta teknik melakukan Penelitian Tindakan Kelas secara benar. Hal ini dibuktikan dari pernyataan alumni diklat yang menyatakan bahwa, "Dampak bagi guru sendiri dapat lebih menguasai bagaimana menyusun PTK yang baik. Dan lebih terarah dalam melaksanakan proses pembelajaran "(01)

Informan berikutnya menyatakan dampak diklat PTK Pola Baru terhadap alumni seperti pada kutipan hasil wawancara Dari data penelitian kuantitatif yang disandingkan dengan data penelitian kualitatif dapatlah dianalisis bahwa: efektivitas DTSPTK Pola Baru di Kantor Kementerian Agama Kota Mataram didukung oleh kesungguhan para alumni dalam mengikuti diklat.

Pada aspek peningkatan kompetensi pengetahuan, rata- rata alumni mengalami peningkatan dan mampu mengimplementasikannya dalam tugas sehari- hari. 
“... Pesrta didik suka banget, sangat menyenangkan bagi anak. perubahan bolus ..timus..dalam konsep pencernaan makanan memerlukan waktu yang cukup panjang. Dengan menerapkan model pembelajaran drama pada pelajaran IPA meningkatkan daya ingat dan pemahaman siswa lebih mendalam"

Melalui tuturan salah satu alumni yakni (02) penerapan model pembelajaran drama pada pelajaran IPA membuat akademisi di Universitas Mataram penasaran, sehingga diundanglah guru dimaksud dan disuruh mempresentasikan penerapan model dramanya di depan Profesor dosen Universitas Mataram tersebut. Demikian tuturannya,

"Sempat diundang ke UNRAM presentasi di hadapan Prof di UNRAM disampaikan kepada Profesor, lalu disuruh bikin "workshop" tentang penerapan model drama dalam penceraan makanan llustrasi ini menunjukkan dengan jelas, bahwa guru sangat paham tentang konsep ber-PTK dan mampu menerapkannya di kelas. Sampai memberikan hasil yang signifikan yakni peserta didik memiliki pemahaman yang mendalam dan membekas pada memori jangka panjang.

Ada hal yang menarik di samping pernyataan di atas. Menurut penuturan alumni (03) menyatakan bahwa, pada saat kegiatan Diklat PTK Pola baru, mereka mampu mengerjakannya karena ada tuntutan target harus lulus dan adanya pendampingan dari widyaiswara. Hal ini menunjukkan masih adanya ketergantungan guru kepada unsur lain di luar dirinya sendiri.

\section{Dampak DTSPTK Pola Baru terhadap Penerapan Kompetensi Keterampilan}

Namun hal tersebut tidak berlaku umum. Karena ada beberapa guru yang tetap mau melaksanakan Penelitian Tindakan Kelas, meskipun sudah tidak menjadi peserta diklat. Mereka menyadari bahwa dengan melaksanakan penelitian tindakan kelas maka keprofesian sebagai guru makin meningkat. Di samping menulis hasil penelitian dan diseminarkan merupakan salah satu unsur wajib bagi guru yang menduduki golongan III/d ke atas. berikut tutrannya,

Informan 04:" pertama- tama setelah mengikuti diklat PTK menambah wawasan, merasa tidak ada apa- apanya, antusias semakin tinggi pingin melakukan yang baru, ingin melakukan yang baru, merasa tertantang untuk melakukan hal- hal yang baru" dan hasil Penelitian yang diseminarkan sangat membantu secara pribadi untuk kenaikan pangkat"

\section{Dampak DTSPTKPola Baru terhadap Peningkatan Kinerja}

Pernyataan dalam kutipan di atas, merupakan salah satu bukti bahwa DTSPTK Pola Baru berdampak terhadap peningkatan kinerja guru. Buktinya guru merasa tertantang, ingin melakukan yang baru, ini menunjukkan peningkatan kinerja.

Data yang sangat mendukung pernyataan alumni dimaksud adalah adanya sederet prestasi yang diraih peserta didik bimbingan guru tersebut. Diantaranya adalah meraih kejuaraan Kompetisi Sains Madrasah di tingkat kota Mataram maupun Provinsi Nusa Tenggara barat. Pernyataan informan lain terkait peningkatan kinerja tampak pada kutipan berikut.

" semakin semangat untuk mencari model - model pembelajaran yang lain semakin bersemangat lagi mencari model lain: seperti inkuiri. Punya rencana buat PTK lagi ada, apalagi utk kenaikan pangkat harus ada PTK.

"PTK hasil Diklat sudah digunakan untuk kenaikan pangkat dari III c- IIId"

"di samping menambah wawasan, kualitas pembelajaran lebih meningkat. sebelumnya: model pembelajaran yang tidak beragam, anak- anak bosan"

"Dalam PTK Diklat, saya menerapkan Model TGT ada mainnya, anak- anak antusias, karena ada diskusi, ada turnamen, anak- anak senang sekali, tanpa merasa belajar" 
"Karena itu, saya jadi semakin bersemangat untuk mencari model- model baru yang lebih menantang"

Hal tersebut di atas, sangat berkaitan dengan dampak DTSPTK Pola baru terhadap peningkatan kinerja alumni. Bagi alumni yang sangat menyadari kedudukannya sebagai guru yang profesional, menulis PTK sudah menjadi salah satu kebutuhan untuk meningkatkan keprofesiannya, namun bagi alumni yang masih sulit mengalami perubahan, hal ini menjadi salah satu kendala dalam peningkatan kinerja maupun karirnya. Pernyataan informan yang lain berikut ini.

Informan 06:

"alhamdulillah dengan mengikuti PTK Pola Baru, saya sebelumnya jarang menggunakan media. Setelah ada diklat PTK Pola Baru saya menggunakan media, anak- anak lebih antusias, setelah menggunakan media sebagian besar ( 29 dari 30 siswa) yang mau berinteraksi dan aktif dalam belajar"

"Saya menggunakan media untuk memudahkan siswa media kartu utk kelas III ( memasangkan kartu) berkelompok bergiliran"

"Awalnya dulu saya ceramah dan tanya jawab"

"Saat PTK saya mulai menggunakan media, siswa semangat, antusias, yang bertanya, mudah diingat, media kartu ( model index Card mach)

Pernyataan informan (09)

"Dampak PTK Pola baru, tampak adanya motivasi dari siswa karena guru menerapkan langkahlangkah model pembelajaran dengan sungguh - sungguh sesuai seluk beluknya, sesuai dengan sintaknya"(10)

Inilah pernyataan informan terkait dampak DTSPTK terhadap peningkatan kinerja.

Informan 10: "Bismillah, alhamdulillah, Diklat PTK Pola Baru yang difasilitasi oleh Balai Diklat tentunya berdampak cukup signifikan dari berbagai aspek. Alhamdulillah saya merasakan Dampaknya cukup signifikan bagi guru, siswa, dan madrasah. Diklat PTK memberikan pencerahan"

"Menambah hasanah keilmuan. Dari adanya Diklat PTK Pola Baru memotivasi teman - teman guru yang lain untuk mencoba melakukan PTK".

Dari hasil penelitian tampak bahwa dampak DTSPTK Pola baru efektif dalam upaya peningkatan kinerja alumni. Meskipun masih ada yang mengkhawatirkan penerapan berbagai model pembelajaran yang bervariasi sebagaisalah satu variabel tindakan dalam ber-PTK ini hanya dilakukan pada saat diklat saja. Hal ini disebabkan adanya tuntutan target materi yang mesti dipenuhi. Seperti tampak pada penuturan berikut.

Informan 01: "masalah bagi guru : jangan sampai guru berinovasi ketika ber-PTK saja, setelah tidak ber-PTK kembali seperti semula. karena kejar materi sesuai target, karena adanya ujian bersama di kota Mataram"

\section{Dampak DTSPTK terhadap Peningkatan Karir}

Pada aspek peningkatan karir alumni, pada umumnya hasil Laporan PTK Pola Baru yang sudah diseminarkan dan dihadiri oleh minimal 15 guru dari tiga sekolah sejenjang sudah memenuhi syarat pengajuan angka kredit dari unsur pengembangan profesi. Namun karena berbagai hal, masih 
ada guru yang sedikit terkendala secara teknis dalam pengajuan angka kredit sebagai salah satu bentuk peningkatan karir.

Berdasarkan data yang peneliti peroleh, dari alumni diklat terdapat 18 alumni yang sudah memanfaatkan hasil diklat berupa Laporan Penelitian Tindakan Kelas yang diseminarkan sebagai unsur Pengembangan Profesi dan diakui dan dinilai sehingga guru tersebut bisa naik pangkat.

(informan 07)" Hasil seminar PTK sudah dipakai untuk naik pangat dari gol III b ke Gol III"

ada informan yang menyatakan hasil PTK nya belum diusulkan, karena baru saja naik pangkat.

(informan 03) "Belum digunakan untuk kenaikan pangkat, karena baru saja naik pangkat di tahun 2017"

Pernyataan informan lain berbeda lagi, dia belum naik pangkat karena belum tahu secara langsung praktik ber- PTK, setelah mengikuti DTSPTK Pola Baru, baru mendapatkan pengalaman langsung dan sangat paham dengan proses ber- PTK.

(informan .....06) "Dengan adanya PTK Pola Baru, kami menghasilkan laporan PTK yang lengkap dan siap diajukan untuk kenaikan pangkat. Saya sudah 6 tahun di III c, dan mandeg karena belum tahu bagaimana menyusun PTK. Setelah mengikuti diklat PTK baru paham bagaimana melakukan PTK sampai penyusunan laporan dan seminar serta bisa mengusulkan untk kenaikan pangkat. Laporan PTK lengkap dan diseminarkan sudah siap untuk diajukan angka kreditnya dari unsur Publikasi IImiah"

Ada juga informan yang menyampaikan bahwa proses usulan DUPAK sudah dilakukan dan dinyatakan diterima. Namun karena ada satu dan lain hal, maka SK sampai saat ini belum diterima.

(informan 15) "Hasil PTK sudah diusulkan sebagai penilaian angka kredit guru, namun karena satu dan lain hal SK belum sampai di tangan"

Dari uraian tersebut, sebenarnya hasil Seminar Hasil Penelitian PTK yang diselenggarakan oleh BDK Denpasar sudah siap untuk diajukan sebagai angka kredit unsur pengembanga profesi, namun ada beberapa faktor teknis yang menjadi kendala sehingga belum berhasil untuk naik pangkat.

\section{Aspek dukungan pimpinan dalam pelaksanaan tugas alumni}

Pada umumnya tidak ada kendala berarti. Secara umum, pimpinan sangat mendukung alumni dalam melaksanakan penelitian tindakan kelas, baik pada saat diklat maupun pasca diklat.

\section{Aspek rencana perubahan sebagai dampak DTSPTK Pola baru}

Pada aspek rencana perubahan, yakni berupa rencana judul PTK yang siap dilaksanakan belum menunjukkan hasil yang memuaskan. Dari sejumlah alumni, baru 9 (sembilan) judul PTK baru yang ditulis. Hal ini disebabkan alasan klasik, seperti kesibukan tugas pokok sehari- hari ditambah dengan tugas tambahan lainnya seperti sebagai bendahara BOS, sebagai wali kelas, dan yang lainnya. Seperti tampak pada pernyataan informan di bawah ini.

(informan 04) "Pingin buat PTK lagi, namun kendala kesibukan tugas sbg wali kelas kadang - kadang gak sempat lagi" 


\section{Simpulan}

Dari pembahasan penelitian dapat disimpulkan bahwa evaluasi pasca Diklat Teknis Substantif Penelitian Tindakan Kelas (DTSPTK) Pola Baru di Balai Diklat Keagamaan Denpasar khususnya di lingkungan Kantor Kementerian Agama Kota Mataram secara umum efektif. Bersumber pada data kuantitatif dapat disajikan hasil penelitian sebagai berikut. Aspek penerapan kompetensi pengetahuan mencapai angka 88,00\% (efektif); pada aspek penerapan kompetensi keterampilan $86,10 \%$ (efektif); aspek peningkatan kinerja menduduki posisi $88,00 \%$ (efektif); aspek peningkatan karir juga pada posisi $87,10 \%$ (efektif); dan aspek dukungan pimpinan pada angka $86,80 \%$ (efektif) serta aspek rencana perubahan mencapai angka 85,90\% (efektif)

Data kuantitatif diperdalam melalui data kualitatif, diperoleh hasil pada umumnya sejalan dengan data kuantitatif. Namun demikian ada satu hal yang tidak sebanding dengan data kuantitatif, yakni pada aspek rencana perubahan. Hal ini merupakan bagian dari evaluasi terhadap penyelenggaraan diklat, sebagai bahan pembenahan dan perlu dipikirkan alternatif solusinya demi perbaikan program di masa yang akan datang.

\section{Daftar Pustaka}

Cresswell, John W. 2014. Resesarch Design, Qualitative, Quantitative and Mix Methods Approaches, USA, Sage Publication.

Gomes, Faustini . Cardoso., 2003, Manajemen Sumber Daya Manusia, Penerbit Andi, Yogyakarta Patilima, Hamid. 2007 Metode Penelitian Kualitatif, Bandung Alfabeta (cetakan kedua).

Milles, Mathew B and A Michael Huberman. 1992 Analisis Data Kualitatif, terjemahan Jakarta, UI Press.

Peraturan Menteri Agama (PMA) nomor 75 Tahun 2015 tentang Pedoman Penyelenggaraan Pendidikan dan Pelatihan Pegawai pada Kementerian Agama.

Peraturan Lembaga Administrasi Negara Nomor 12 Tahun 2013 tentang Pedoman Penyelenggaraan Pendidikan dan Pelatihan Kepemimpinan Tingkat III.

Sugiyono. 2011. Metode Penelitian Kuantitatif, R \& D, Bandung, Alfabeta. 